\title{
MANFAAT STIMULUS VERTEBRA CERVIKALIS KE 5-6 DAN STIMULUS OTOT RECTUS ABDOMINIS TERHADAP PERUBAHAN TFU IBU POST PARTUM PER VAGINAM
}

\author{
THE BENEFIT OF THE STIMULUS CERVIKALIS VERTEBRAE 5-6 AND \\ RECTUS ABDOMINIS MUSCLE AGAINST THE STIMULUS CHANGES OF \\ MATERNAL TFU POST PARTUM
}

\author{
Suryanti ${ }^{1)}$ Dewi Ambarwati ${ }^{2)}$ \\ 1)2) Program Studi Diploma III Kebidanan \\ Akademi Kebidanan Graha Mandiri Cilacap \\ Email : Suryanti@gmail.com
}

\begin{abstract}
ABSTRAK
Latar Belakang : Involusi uterus merupakan proses normal pada masa nifas dan dimulai segera setelah plasenta lahir akibat kontraksi otot-otot polos uterus. Stimulus adalah perangsang organism tubuh atau reseptor lain untuk menjadi aktif. Pemberian stimulus Vertebra Cervikal dapat merangsang hipofisis anterior dan posterior untuk mengeluarkan hormon oksitosin. Hormon oksitosin akan memicu kontraksi otot polos pada uterus. Tujuan : Penelitian ini bertujuan untuk manfaat stimulus vertebra cervikalis ke 5-6 dan stimulus otot rectus abdominis terhadap perubahan tfu ibu post partum pervaginam. Metode: Populasi dan sampel dalam penelitian ini adalah ibu postpartum pervaginam di Ruang Nifas RSUD Dr. Soeselo Slawi. penelitian ini menggunakan $t$-test of relate. Hasil : Dalam uji hipotesis didapatkan $t$ hitung $\geq t$ table (10.863 $\geq 1.980)$, maka dapat disimpulkan Ho ditolak dan Ha diterima. Kesimpulan : Artinya terdapat manfaat stimulus vertebra cervikalis ke 5-6 dan stimulus otot rectus abdominis terhadap perubahan tinggi fundus uteri ibu postpartum pervaginam.
\end{abstract}

Kata Kunci : Stimulus Vertebra Cervikalis Ke 5-6, Stimulus Otot Rectus Abdominis, Tinggi Fundus Uteri

\begin{abstract}
Background: involution of the uterus is a normal process in the post-partum period and started immediately after delivery of the placenta caused by contraction of smooth muscles of the uterus. The stimulus is the stimulus to the organism's body or other receptors to be active. Giving stimulus cervical vertebrae can stimulate the anterior and posterior pituitary to secrete the hormone oxytocin. The hormone oxytocin triggers contraction of smooth muscle of the uterus. Objective: This study aimed to benefit vertebra stimulus cervikalis to 5-6 and the rectus abdominis muscle stimulus to changes in maternal postpartum vaginal TFU. Methods: Population and sample in this research is the mother postpartum vaginal at room Postpartum Hospital Dr. Soeselo Slawi. This research using $t$-test of the relate. Results: In a hypothesis test obtained $t$ arithmetic $\geq t$ table $(1.980 \geq 10,863)$, it can be concluded that Ho refused and Ha accepted. Conclusion: This means that there are benefits of stimulus vertebra cervikalis to 5-6 and the rectus abdominis muscle stimulus to changes in the fundus uteri postpartum maternal vaginal.
\end{abstract}

Keywords: Stimulus Cervikalis Vertebrae To 5-6, Rectus Abdominis Muscle Stimulus, the height of the Fundus Uteri 


\section{PENDAHULUAN}

Masa nifas merupakan masa setelah persalinan selesai sampai alat-alat kandungan kembali seperti keadaan sebelum hamil, dan berlangsung sekitar 68 minggu (Bahiyatun, 2009).

Berdasarkan Survei Demografi dan Kesehatan Indonesia (SDKI) tahun 2012, angka kematian ibu di Indonesia masih tinggi sebesar 359 per 100.000 kelahiran hidup. Angka ini mengalami peningkatan yang cukup tinggi jika dibandingkan dengan data Angka Kematian Ibu menurut SDKI tahun 2007, yaitu sebesar 228 per 100.000 kelahiran hidup. Angka ini masih jauh dari target MDGs (Millenium Development Goals) ke-5 yaitu menurunkan angka kematian ibu (AKI) menjadi 102/ 100.000 kelahiran hidup pada tahun 2015 (KemenKes RI, 2014).

Proses involusi uteri dan kejadian diastasis rectus abdominis (pemisahan otot-otot perut) merupakan gangguan proses pemulihan kondisi fisik ibu postpartum. Gangguan proses involusi dan pemisahan otot-otot perut (diastasis rectus abdominis) ini dapat menyebabkan perdarahan post partum (Ambarwati, 2008).

Kontraksi otot-otot perut akan membantu proses involusi yang dimulai setelah plasenta dilahirkan. Ambulasi secepat mungkin dengan frekuensi sering sangat diperlukan dalam proses involusi. Kelancaran proses involusi dapat dideteksi dengan pemeriksaan lochia, konsistensi uterus, dan pengukuran tinggi fundus uteri (Williams dan Wilkins, 2004).

Proses involusi uteri di pengaruhi oleh kekuatan kontraksi uterus. Menurut Cunningham tahun 2006, Stimulus vertebra cervikalis ke 5-6 akan mempercepat kerja saraf parasimpatis untuk menyampaikan perintah ke otak bagian belakang sehingga hormon oksitosin keluar. Hormon oksitosin ini berguna untuk memperkuat dan mengatur kontraksi uterus. Proses involusi uterus akan berjalan dengan lancar apabila dilakukan stimulus otot rectus abdominis yang berguna untuk melancarkan sirkulasi oksigen dalam darah dengan cara mengontaksikan dan meretraksikan otototot yang berada dalam uterus (Salamah, 2003).

\section{METODE PENELITIAN}

Penelitian dilakukan di Rumah Sakit Umum Daerah Dr. Soeselo Slawi. Penelitian dilakukan pada bulan Nopember 2015 sampai dengan Maret 2016 dan pengambilan data dilakukan pada tanggal 4 Januari sampai dengan 19 Pebruari 2016. Populasi dalam penelitian ini adalah ibu postpartum pervaginam di Ruang Nifas RSUD Dr. Soeselo Slawi. Sampel dalam penelitian ini adalah ibu post partum pervaginam yang dirawat di Ruang Nifas RSUD Dr. Soeselo Slawi. Sampel dalam penelitian ini adalah ibu post partum pervaginam. Penelitian ini menggunakan sampling/sampel insidental yaitu teknik penentuan sampel berdasarkan kebetulan. Siapa saja yang secara kebetulan bertemu dengan peneliti dapat digunakan sebagai sampel bila dipandang orang yang kebetulan ditemui tersebut cocok sebagai sumber data (Notoatmodjo, 2008). Teknis analisa data yang digunakan untuk menganalisa rumusan masalah dan hipotesa dalam penelitian ini menggunakan t-test of relate dimana teknik statistik ini digunakan untuk menguji hipotesis komparatif. Uji T-test of related dilakukan dengan menggunakan software SPSS. Uji T-test of related dilakukan untuk menguji hipotesis penelitian.

Dengan derajat kepercayaan $95 \%$ dan derajat kebebasan sebesar 5\% maka criteria pengujian ditentukan dengan rumus 
"Jika thitung $\leq$ ttabel maka Ho diterima, Ha ditolak. Jika $t$ hitung $\geq t$ tabel maka Ho ditolak, Ha diterima”.

\section{HASIL DAN PEMBAHASAN}

Tabel Distribusi data hasil sampel pada kelompok ibu post partum pervaginam sebelum dan sesudah dilakukan tindakan.

\begin{tabular}{ccccccc}
\hline & N & Min & Max & Sum & Mean & $\begin{array}{c}\text { Std. } \\
\text { Deviation }\end{array}$ \\
\hline $\begin{array}{c}\text { TFU } \\
\text { Sebelum }\end{array}$ & 99 & 12 & 16 & 1424 & 14.38 & 0.83 \\
\hline $\begin{array}{c}\text { TFU } \\
\text { Sesudah }\end{array}$ & 99 & 11 & 15 & 1357 & 13.70 & 0.87 \\
\hline
\end{tabular}

Berdasarkan data penelitian yang dilakukan di RSUD Soesilo Slawi periode 4 Januari sampai 19 Februari 2016 menunjukan bahwa kejadian gangguan proses involusi uterus pada ibu post partum bukan hanya dialami oleh ibu dengan usia diatas 35 tahun oleh karena faktor paritas ataupun usia, namun dari 99 ibu post partum yang mengalami gangguan proses involusi uterus ternyata pada ibu post partum dengan usia 20-35 tahun yaitu sebanyak $74,75 \%$.

Tabel Hasil Uji Paired sample t-test sampel TFU pada kelompok ibu post partum pervaginam sebelum dan sesudah dilakukan tindakan

\begin{tabular}{lccccc}
\hline & $\begin{array}{c}\text { Mea } \\
\mathbf{n}\end{array}$ & $\begin{array}{c}\text { Std. } \\
\text { Deviatio } \\
\mathbf{n}\end{array}$ & t & df & $\begin{array}{c}\text { Sig. } \\
\mathbf{2 -} \\
\text { tailed } \\
\mathbf{~}\end{array}$ \\
\hline TFU & .676 & .619 & 10.86 & 9 & .000 \\
Sebelu & & & 3 & 8 & \\
m - & & & & & \\
TFU & & & & & \\
Sesuda & & & & & \\
h & & & & & \\
\hline
\end{tabular}

Kondisi ibu dengan usia diatas 35 tahun atau multiparitas akan mengganggu proses pemulihan fisik bagi ibu sendiri, seperti yang di sampaikan oleh Ambarwati (2008) bahwasanya gangguan proses involusi dan pemisahan otot-otot perut (diastasis rectus abdominis) ini dapat menyebabkan perdarahan post partum. Kontraksi otot-otot perut akan membantu proses involusi yang dimulai setelah plasenta dilahirkan. Ambulasi secepat mungkin dengan frekuensi sering sangat diperlukan dalam proses involusi. Kelancaran proses involusi dapat dideteksi dengan pemeriksaan lochia, konsistensi uterus, dan pengukuran tinggi fundus uteri (Williams dan Wilkins, 2004).

Proses involusi uteri di pengaruhi oleh kekuatan kontraksi uterus. Menurut Cunningham tahun 2006, Stimulus vertebra cervikalis ke 5-6 akan mempercepat kerja saraf parasimpatis untuk menyampaikan perintah ke otak bagian belakang sehingga hormon oksitosin keluar. Hormon oksitosin ini berguna untuk memperkuat dan mengatur kontraksi uterus. Proses involusi uterus akan berjalan dengan lancar apabila dilakukan stimulus otot rectus abdominis yang berguna untuk melancarkan sirkulasi oksigen dalam darah dengan cara mengontaksikan dan meretraksikan otot-otot yang berada dalam uterus (Salamah, 2003).

\section{SIMPULAN}

Kesimpulan dalam penelitian ini terdapat manfaat stimulus vertebra cervikalis ke 5-6 dan stimulus otot rectus abdominis terhadap perubahan tinggi fundus uteri ibu postpartum pervaginam.

\section{DAFTAR PUSTAKA}

Ambarwati, E, \& Wulandari, D. 2008. Asuhan Kebidanan Nifas. Yogyakarta: Cendekia Press 
Bahiyatun. 2009. Buku Ajar Asuhan Kebidanan Nifas Normal. Jakarta: EGC

Bobak, et.al. 2004. Buku Ajar Keperawatan Maternitas Edisi 4. Jakarta : EGC

Cunningham, F. Gerry. 2006. Obstetri William Vol. 1. Jakarta: EGC

DinKes Provinsi Jawa Tengah. 2009. Profil Kesehatan Provinsi Jawa Tengah. Semarang: Dinas Kesehatan Provinsi Jawa Tengah

Farrer, H. 2002. Perawatan Maternitas. Edisi Ke-2. Jakarta : EGC

Guyton, Arthur C. 1997. Buku Ajar Fisiologi Kedokteran. Jakarta : EGC

Jordan, S. 2004. Farmakologi Kebidanan. Jakarta : EGC

Juliansyah. 2011. Metodologi Penelitian. Jakarta: Kencana

KemenKes RI, 2014. Pusat Data dan Informasi Kementerian Kesehatan RI. Jakarta : KemenKes RI

Mochtar, Rustam. 1998. Sinopsis Obstetri Jilid I. Jakarta : EGC

Pillitery. 2003. Maternal And Child Health Nursing. Buku I. Fourth Edition. Philadelphia : Lippincott

Pusdiknakes. 2003. Asuhan Post Partum. Jakarta : Pusdiknakes

Sloane, Ethel. 2003. Anatomi dan Fisiologi. Jakarta: EGC

Sugiyono. 2008. Statistik Nonparametris. Bandung: Alfabeta

Sugiyono. 2010. Statistik Untuk Penelitian. Bandung: Alfabeta

Suharsimi. 2006. Prosedur Penelitian. Jakarta: PT Bina Cipta

Sweet, Betty R. 2000. Mayes Midwifery a text books for midwives. Sidney : Bailliere London Philadelphia Toronto.

Varney, dkk. 2004. Buku Ajar Asuhan Kebidanan Vol 1 Edisi 4. Jakarta : EGC
Verralls, S. 2003. Anatomi dan Fisiologi Terapan dalam Kebidanan. Jakarta : EGC

Wiknjosastro, Hanifa. 2007. Ilmu Kebidanan. Jakarta : Yayasan Bina Pustaka Sarwono Prawirohardjo 